\title{
AYAH TANGGUH, KELUARGA UTUH : POLA ASUH AYAH PADA KELUARGA BURUH MIGRAN PEREMPUAN DI KABUPATEN BANYUMAS
}

\author{
Tyas Retno Wulan`), Dalhar Shodiq, Sri Wijayanti, Dyah Woro Dwi Lestari, Ariadne Tri \\ Hapsari, Eri Wahyuningsih, Hendri Restuadhi
}

Pusat Penelitian Gender, Anak dan Pelayanan Masyarakat Lembaga Penelitian dan Pengabdian Masyarakat (LPPM), Universitas Jendral Soedirman, Purwokerto 53122, Indonesia

\section{*) Email: tyasretnounsoed@gmail.com}

\begin{abstract}
Abstrak
Banyumas sebagai salah satu basis Buruh Migran Indonesia (BMI), setiap tahun memberangkatkan sekitar 2.000 Buruh Migran Perempuan (BMP). Pengasuhan anak kemudian digantikan oleh peran ayah. Penelitian ini bertujuan mengidentifikasi peran ayah dalam pengasuhan anak. Penelitian menggunakan paradigma konstruktivis dengan pertimbangan bahwa paradigma ini dianggap memiliki kemampuan untuk mengungkap detildetil budaya komunitas tertentu dengan cara memahami latar belakang budayanya secara alamiah dengan point of view subyek yang diteliti. Metode yang digunakan adalah kualitatif sehingga diperlukan keterampilan dari peneliti untuk mengungkap lukisan mendalam (thick description) tentang kehidupan anak yang ditinggalkan orang tuanya (Children Left Behind/CLB) di Kabupaten Banyumas dengan 10 informan. Hasil penelitian menunjukkan bahwa selama ditinggalkan istri bekerja ke luar negeri, ayah berperan sangat penting dalam mengasuh anakanaknya. Saat anak masih balita, ayah menjalankan peran instrumental dan ekspresif. Sementara itu, saat anak remaja dan permasalahan semakin kompleks, sosok ayah yang dibutuhkan adalah yang lebih komunikatif, bisa mencurahkan perhatian, mendengarkan keluhan dan kegelisahan serta bisa dijadikan panutan dan memegang kendali. Keluarga BMP yang utuh akan tercipta jika ayah tangguh, yaitu memiliki kekuatan, mau bekerja keras, serta mau belajar tentang pola asuh yang lebih otoritatif.
\end{abstract}

Kata kunci: anak BMI, ayah, Buruh Migran Perempuan, keluarga, pola asuh

\section{A Tough Father for an Intact Family: \\ Father's Parenting in Nurturing of the Children Left Behind by Women Migrant Workers in Banyumas Regency, Indonesia}

\begin{abstract}
Banyumas as one of the bases of Indonesian Migrant Workers (BMI), annually dispatches about 2.000 Women Migrant Workers (BMP). Parenting is then replaced by the father's role. This study aimed to identify the role of father in child care. The study used a constructivist paradigm becaouse of the consideration that is the paradigm has the ability to reveal details of a particular community culture by understanding its natural cultural arrangement by research subject's point of view. The method used is qualitative, requiring the skill of the researcher to reveal the thick description about the daily life of the child left behind in Banyumas Regency among 10 informants as participants of this research. The research result showed that when the mother left the children to go abroad as migrant worker, the father's role to nurture the child became important. When the early childhood, fathers had significant roles for instrumental and expressive functions. Meanwhile, while the children were teenagers and had more complex problems, the father was needed to be more communicative, assertive, and able to reflective listen to the children's problems and feeling. Therefore, for the women migrant's family; the tougher the father, the stronger the family. It means that the father should have the strong will, willing to harder work, and also willing to more learn about how to practice authoritative parenting.
\end{abstract}

Keywords: Children Left Behind (CLB), father, family, women migrant worker, parenting

\section{PENDAHULUAN}

Migrasi internasional menyebabkan sebagian besar keluarga di seluruh belahan dunia harus mengalami situasi salah satu atau kedua orang tua jauh dari anak-anaknya dikarenakan tuntutan dalam mencari nafkah di negara lain. Kondisi demikian membuat orang tua mengalami kesulitan untuk menyediakan kebutuhan dasar bagi anak-anaknya. Kondisi ini yang memunculkan istilah anak yang ditinggalkan (Children Left Behind). UNICEF 
(2010) mendefinisikan Children Left Behind (CLB) sebagai kondisi-kondisi yang harus dihadapi anak-anak berkaitan dengan kesenjangan kesejahteraan materi, pendidikan, dan kesehatan saat mereka ditinggalkan orang tua mereka bermigrasi ke luar negeri. Berdasarkan data BNP2TKI (2015), penempatan BMI (Buruh Migran Indonesia) selama tahun 2011-2015 didominasi oleh para BMI yang berstatus sudah menikah dan berjenis kelamin perempuan. KPAl memprediksi setiap tahun ada sekitar 11,2 juta anak kehilangan kasih sayang karena menjadi CLB. Pada keluarga Buruh Migran Perempuan (BMP), fenomena CLB semakin besar peluangnya karena peran pengasuhan yang biasanya dilakukan oleh ibu tidak dapat dijalankan.

Undang-Undang Nomor 35 Tahun 2014 tentang perubahan Undang-Undang Nomor 23 Tahun 2002 tentang Perlindungan Anak menyatakan bahwa setiap anak berhak untuk dapat hidup, tumbuh, berkembang, dan berpartisipasi secara wajar sesuai dengan harkat dan martabat kemanusiaan, serta mendapat perlindungan dari kekerasan dan diskriminasi. Keluarga adalah lembaga pertama yang bertanggung jawab agar anak mendapatkan perlindungan tersebut. Keluarga menjadi tempat paling dibutuhkan seorang anak, namun dalam kenyataannya keluarga mudah berubah karena kondisi eksternal di luar keluarga. Salah satu faktor yang membuat struktur keluarga berubah adalah migrasi yang dilakukan oleh ayah atau ibu untuk jangka waktu yang lama, dan pada akhirnya membuat anak-anak tidak dalam pengawasan (Blood,1972).

Migrasi bisa dikategorikan sebagai perubahan yang direncanakan (planned social change), namun seringkali dalam proses migrasi internasional yang telah direncanakan akan terjadi perubahan yang diharapkan (intended change) dan perubahan yang tidak diharapkan (unintended change). Intended change dalam konteks ini bisa dimaknai sebagai dampak positif proses migrasi, namun jika tidak direncanakan dengan baik maka akan timbullah unintended change, yang bisa dianggap sebagai dampak sosial (social cost) migrasi. Beberapa kajian yang melihat unintended change migrasi antara lain tentang perubahan fungsi dan struktur keluarga yang berdampak pada meningkatnya angka perceraian di kalangan keluarga dan masyarakat asal migran, dianggap sebagai dampak negatif migrasi internasional (Wulan, 2010; Mantra, Kasto, \& Yeremias, 1998;
Tamtiari, 1999; 2000; Sukamdi, 2001; Kustini, 2002).

Hasil penelitian Puspitawati dan Setioningsih (2011) terhadap 47 keluarga BMI di Sukabumi menunjukkan bahwa tiga perlima anak BMI mempunyai stres kategori sedang dan tinggi. Hampir tiga perempat anak mempunyai prestasi kurang memuaskan dan semakin lama ibu menjadi BMI maka semakin memperburuk kondisi anak. Dari beberapa studi menunjukkan bahwa CLB yaitu anakanak yang ditinggalkan orang tuanya (khususnya ibu) bermigrasi ke luar negeri menjadi ciri social cost proses migrasi internasional. Berbagai penelitian juga menunjukkan bahwa anak-anak yang ditinggalkan salah satu atau kedua orang tuanya secara bersama-sama akan rentan menghadapi banyak menghadapi permasalahan. Temuan Cortes (2008) di Filipina; Botezat dan Friedhelm (2014) di Romania; Graham dan Jordan (2011) menunjukkan persoalan yang sama bahwa anak BMI yang ditinggalkan mengalami proses keterlambatan belajar dan rasa kurang percaya diri. Temuan Sukamdi (2015) yang membandingkan kondisi anak buruh migran dan nonmigran di Sukabumi, Tasikmalaya, Ponorogo, dan Tulungagung menunjukkan bahwa anak migran memiliki kondisi psikologis yang kurang baik apabila dibandingkan dengan nonmigran. Kondisi psikologis yang dimaksud adalah mudah marah, bermasalah dengan teman sebaya, dan hiperaktif.

Kabupaten Banyumas merupakan daerah pengirim BMI nomor empat terbanyak di Provinsi Jawa Tengah dan nomor 16 dari 25 kabupaten yang dikategorikan pengirim BMI terbanyak di Indonesia (Puslitfo BNP2TKI, 2017). Setiap tahun jumlah BMI yang diberangkatkan dari Kabupaten Banyumas selalu mengalami peningkatan. Data tiga tahun terakhir menunjukkan kondisi tersebut. Data Dinas Sosial, Tenaga Kerja, dan Transmigrasi Kabupaten Banyumas (2016) melaporkan bahwa pada tahun 2013 terdapat 92 laki-laki dan 1.789 perempuan penduduk Kabupaten Banyumas yang menjadi buruh migran ke luar negeri. Angka tersebut meningkat menjadi 197 laki-laki dan 2.020 perempuan pada Tahun 2014 dan 163 laki-laki dan 1.956 perempuan di Tahun 2015. Taiwan, Malaysia, Singapura, dan Hongkong merupakan negara tujuan utama dari pada BMI yang berasal dari Kabupaten Banyumas. Berdasarkan data tersebut, selama tiga tahun terakhir, jumlah buruh migran asal Banyumas didominasi oleh kelompok perempuan. 
Problematika keluarga BMI seperti halnya penelitian-penelitian sebelumnya juga ditemukan di Kabupaten Banyumas. Hasil penelitian Restuadhi (2016) menunjukkan bahwa beberapa orang suami BMP membentuk kelompok yang salah satu aktivitasnya pergi ke lokasi prostitusi bersamasama. Dapat dibayangkan kondisi anak yang ditinggalkan, saat ibunya harus bekerja ke luar negeri, namun ayah yang mendapatkan kewajiban mengasuh justru memanfaatkan uang dan waktu untuk berfoya-foya. Temuan Pranowo, Wulan, dan Widyastututi (2013) terhadap para CLB di Kabupaten Banyumas menemukan bahwa perasaan anak-anak buruh migran pada umumnya merasa sedih dan tidak ikhlas ibunya pergi ke luar negeri.

Berdasarkan hasil observasi awal di lapangan, juga ditemukan suami BMI yang menghamili anak kandungnya (incest) saat ditinggal istrinya bekerja ke luar negeri. Seruni (2014) dari penelitiannya di tiga desa di Kabupaten Banyumas menyebutkan bahwa kelompok buruh migran di Kabupaten Banyumas didominasi perempuan menikah, kelompok usia produktif (15-64 tahun), dengan lama kerja di luar negeri mencapai lebih dari 10 tahun. Sementara itu, anak yang ditinggalkan berada pada rentang usia 15 bulan hingga 34 tahun yang sebagian besar berada pada usia sekolah dan usia remaja. Hasil penelitian tersebut mengidentifikasi permasalahan pada anak-anak buruh migran yang ditinggalkan. Hampir semuanya menunujukkan masalah serupa yaitu ketidak patuhan (Narsidah et al., 2016). Penelitian lain, di Kabupaten Banyumas, Jawa Tengah, menunjukkan gambaran yang hampir sama. Keluarga yang salah satu orang tuanya bermigrasi menunjukkan fenomena bahwa pengasuh anak adalah pasangan pada keluarga yang salah satu orang tua yang tinggal, pengasuh anak pada keluarga yang kedua orang tuanya pekerja migran adalah kerabat dekat dari salah satu orang tua, dan juga tidak ada keterlibatan tetangga atau bukan keluarga dalam pengasuhan anak keluarga migran.

Hasil penelitian sebelumnya menunjukkan bahawa masalah yang muncul sebagian besar adalah masalah perilaku anak, terutama anak tidak patuh kepada pengasuh (Wahyuningsih \& Wulan, 2016). Nobles (2013) berdasarkan hasil penelitiannya di Meksiko dengan menggunakan data nasional pada tahun 1992-2005 membuktikan bahwa migrasi internasional berkontribusi terhadap proses perubahan struktur keluarga, selain proses perubahan demografi lainnya, yaitu menurunnya kematian orang dewasa, meningkatnya perceraian dan meningkatnya kelahiran nonmarital. Hasil penelitian Dissanayake et al. (2014) di Srilanka menunjukkan bahwa pada saat kepergian ibunya ke luar negeri untuk bekerja, anak yang ditinggalkan mengalami persoalan dalam pendidikan jika dibandingkan dengan anak yang tidak ditinggalkan ibunya ke luar negeri. Serangkaian penelitian tersebut menunjukkan problematika yang dihadapi anak buruh migran yang memang beresiko tinggi terhadap pemenuhan hak dan tumbuh kembangnya.

Pengasuhan anak selama ini dikonstruksikan dalam masyarakat seolah-olah sebagai tanggung jawab penuh seorang ibu saja. Menurut Goode (2007) pekerjaan dan kewajiban peran utama ayah dan ibu dalam keluarga sudah dikonstruksikan secara jelas. lbu mengasuh anak, menanamkan ikatan badaniah dan rohaniah, tugas sosialnya berhubungan sesuatu yang bersifat ekspresif, emosional atau penggabungan dari keduanya. Ibu bertugas menghibur, merawat, mendamaikan anak yang berselisih. Sementara ayah adalah pemimpin, mengatur tenaga kerja keluarga untuk produksi, pertentangan politik atau perang. Kondisi pada keluarga buruh migran telah terjadi pergeseran peranan di dalam keluarga antara ayah dan ibu. Kepergian ibu menjadi BMP menjadikan perubahan struktur dalam keluarga yang tadinya merupakan struktur keluarga utuh (intact families) menjadi keluarga yang tidak utuh dengan kepala keluarga laki-laki untuk sementara waktu (Puspitawati, 2013). Seperti yang disebutkan oleh Hubeis dalam Puspitawati (2013) tentang perubahan peran perempuan dalam keluarga bahwa seorang laki-laki bekerja dirumah untuk mengurus rumah tangga serta mengasuh anaknya, tugas mencari nafkah dilakukan istrinya. Penelitian Lam, Yeoh, dan Hoang (2013) di Asia Tenggara menjelaskan saat keberangkatan seseorang yang menjadi buruh migran akan berpengaruh terhadap anggota keluarga yang ditinggalkan, ada perubahan peran dalam keluarga untuk menggantikan anggota keluarga yang menjadi buruh migran. Oleh karenanya, menarik mengkaji peran ayah pada keluarga BMP yang selama ini tidak dikonstruksikan dalam masyarakat untuk mengasuh anak, menjadi pihak yang justru paling dominan untuk mengasuh anak. Permasalahan yang mendasar dalam penelitian ini adalah terkait eksplorasi peran ayah dalam mengasuh anak-anak CLB selama ditinggalkan ibu dan mengeksplorasi lebih lanjut praktek pengasuhan yang seperti apa 
yang diterapkan ayah ketika ibu harus bekerja ke luar negeri.

\section{METODE}

Penelitian ini menggunakan paradigma konstruktivis dengan pertimbangan bahwa paradigma ini dianggap memiliki kemampuan untuk mengungkap detail-detail budaya komunitas tertentu dengan cara memahami setting cultural secara alamiah dengan point of view subyek yang diteliti. Metode yang digunakan adalah kualitatif sehingga diperlukan keterampilan dari peneliti untuk mengungkap lukisan mendalam (thick description) tentang kehidupan anak yang ditinggalkan orang tuanya (Children Left Behind) di Kabupaten Banyumas.

Informan utama dalam penelitian ini adalah anak yang ditinggalkan orang tuanya (Children Left Behind), khususnya ditinggalkan oleh ibu untuk bekerja ke luar negeri. Jumlah informan dalam penelitian ini adalah 10 orang. Partisipan dalam penelitian ini dipilih dengan teknik sampling secara purposive, yakni diplih CLB yang sudah remaja dan bisa menceritakan pengalaman hidupnya. Sasaran pendukungnya adalah orang-orang yang mengetahui kehidupan mereka seperti ayah, keluarga besar, dan tokoh masyarakat yang mengetahui kehidupan CLB tersebut.

Teknik pengumpulan data yang digunakan dalam penelitian ini adalah wawancara mendalam (indepth interview) dengan CLB dan orang tua, serta melakukan pengamatan secara terlibat (participant observation) untuk mendapatkan informasi permasalahan yang lebih menyeluruh dan mendalam. Teknik pengumpulan data yang lain adalah FGD (Focus Group Discussion). Lokasi penelitian ini adalah Kabupaten Banyumas, yang merupakan salah satu dari 24 Kabupaten/Kota kantong buruh migran di Indonesia.

Proses analisis data yang digunakan dalam penelitian ini menggunakan model yang dikembangkan oleh Miles dan Huberman (1984) yang lebih dikenal dengan model analisis interaktif. Model analisis ini adalah melalui proses berikut: data yang terkumpul direduksi berupa pokok-pokok temuan penelitian yang relevan dengan bahan penulisan, dan selanjutnya disajikan secara naratif. Reduksi dan penyajian data adalah dua komponen analisis yang dilakukan bersamaan dengan proses pengumpulan data. Proses selanjutnya adalah penarikan kesimpulan, yakni dilakukan setelah proses pengumpulan data, disajikan, dideskripsikan dan kemudian diberi pemaknaan dengan interpretasi logis. Untuk memastikan bahwa hasil penelitian dapat dipertanggungjawabkan maka dilakukan proses validasi data dengan metode triangulasi.Triangulasi data dalam hal ini dilakukan dengan melakukan wawancara terhadap aktivis buruh migran di Kabupaten Banyumas yang bergerak dalam permberdayaan anak buruh migran.

HASIL

\section{Karakteristik Anak Buruh Migran}

Informan utama dalam penelitian ini adalah anak-anak BMI yang berusia remaja, pernah ditinggal ibu bekerja minimal lima tahun dan ayah merupakan pengasuh utama (tidak diserahkan kepada pengasuh lain (keluarga besar). Sementara informan pendukung adalah ayah, ibu (untuk yang sudah kembali) dan tokoh masyarakat yang mengetahui kehidupan CLB tersebut. Karakteristik masingmasing informan tersaji pada Tabel 1.

Bunga adalah anak tunggal dari Keksi. Dia lahir di Yogyakarta berusia 18 tahun saat penelitian dilakukan dan baru saja lulus dari sebuah SMA Negeri di Purwokerto. Saat ini dia telah diterima di Politeknik Negeri di Bandung. Kisah hidupnya selama ditinggalkan ibunya, Keksi, yang bekerja di Hong Kong pernah dibuat film dokumenter dan diputar pada pada tanggal 3 Maret 2013 pada sebuah acara seminar kewirausahaan di Hong Kong. Selanjutnya, Didik adalah anak pertama dari tiga bersaudara, lahir di Banyumas berusia 19 tahun saat penelitian dilakukan, selepas SMP dia melanjutkan sekolah ke STM namun tidak selesai karena dikeluarkan dari sekolah, sempat juga belajar di Kejar Paket B, namun juga dikeluarkan karena memalsukan tanda tangan petugas administrasi. Setahun dari waktu penelitian dilakukan Didik harus berhadapan dengan hukum karena diduga terlibat kasus pencurian. Saat ipenelitian dilakukan, Didik ditahan di penjara menunggu vonis kasusnya selesai. Budi adalah anak pertama dari dua bersaudara, saat ini dia duduk di bangku kelas 6 SD di Banyumas. Ibunya sudah bekerja di Taiwan sejak 5 tahun dari waktu penelitian ini dilakukan dan sempat cuti selama satu bulan, saat ini ibunya kembali bekerja ke Taiwan. Kiki adalah anak kedua dari tiga bersaudara pasangan Bambang dan Ani, saat ini dia duduk di bangku kelas 2, bersekolah di sebuah SMPN di Banyumas. Ibunya bekerja di Arab Saudi selama lima tahun, dan setahun dari waktu penelitian ini 
dilakukan telah kembali berkumpul bersama keluarganya.

Sularso adalah ayah dari dua orang anak perempuan berusia 17 dan 9 tahun, istrinya sudah 3 tahun ini bekerja di Taiwan. Mbah Karto yang sehari-harinya berprofesi sebagai seorang tukang becak memiliki dua orang anak perempuan yang berusia 28 dan 17 tahun. Anak pertama sudah tinggal terpisah dan sudah menikah, anak kedua saat ini duduk di bangku kelas dua sebuah SMK di Banyumas. Istrinya sudah lebih dari 10 tahun bekerja di Arab Saudi dan putus komunikasi dengan keluarga. Peneliti sudah mengupayakan bertanya ke Dinas Sosial, Tenaga Kerja, dan Transmigrasi Kabupaten Banyumas, namun sampai saat ini tidak ada kepastian tentang keberadaan dan nasib dari istrinya. Keksi lahir di Yogyakarta pada tahun 1968, didesak kebutuhan ekonomi dan menyadari minimnya pendidikan yang tidak sampai tamat SD, pada tahun 1999 Keksi memutuskan bekerja di Hong Kong menjadi BMP. Terhitung selama 13 tahun bekerja di Hongkong (1999-2012), Keksi berganti dua majikan. Yanti adalah seorang guru PAUD di sebuah desa di Kabupaten Banyumas. Salah satu anggota keluarganya ada yang menjadi $\mathrm{BMI}$ dan sering mendapatkan laporan tentang keluarga yang menjadi anak BMI. Laporan tersebut mengungkapkan adanya perilaku menyimpang yang dilakukan oleh dua orang anak BMI yang ditinggalkan oleh ayahnya bekerja di Malaysia.

Tabel 1 Karakteristik Informan

\begin{tabular}{|c|c|c|c|c|c|}
\hline $\begin{array}{l}\text { Nama } \\
\text { Samaran }\end{array}$ & $\begin{array}{l}\text { Usia } \\
\text { (th) }\end{array}$ & $\begin{array}{l}\text { Jenis } \\
\text { Kelamin }\end{array}$ & Pendidika & ר Status & Pekerjaan \\
\hline Bunga & 18 & $\begin{array}{l}\text { Peremp } \\
\text { uan }\end{array}$ & $\begin{array}{l}\text { SMA } \\
\text { (baru } \\
\text { saja } \\
\text { tamat) }\end{array}$ & CLB & Pelajar \\
\hline Didik & 19 & Laki-laki & $\begin{array}{l}\text { SMP } \\
\text { tidak } \\
\text { tamat }\end{array}$ & CLB & -- \\
\hline Budi & 12 & Laki-laki & i SD & CLB & Pelajar \\
\hline Kiki & 14 & $\begin{array}{l}\text { Peremp } \\
\text { uan }\end{array}$ & SMP & CLB & Pelajar \\
\hline $\begin{array}{l}\text { Sulars } \\
0\end{array}$ & 42 & Laki-laki & STM & Ayah & Swasta \\
\hline $\begin{array}{l}\text { Mbah } \\
\text { Karto }\end{array}$ & 57 & Laki-laki & SMP & Ayah & Swasta \\
\hline Keksi & 43 & $\begin{array}{l}\text { Peremp } \\
\text { uan }\end{array}$ & SD & Ibu & $\begin{array}{l}\text { Wiraswa } \\
\text { sta }\end{array}$ \\
\hline Yanti & 32 & $\begin{array}{l}\text { Peremp } \\
\text { uan }\end{array}$ & S1 & $\begin{array}{l}\text { Keluar } \\
\text { ga } \\
\text { CLB }\end{array}$ & Guru \\
\hline Untung & 47 & Laki-laki & i SMA & $\begin{array}{l}\text { Kepala } \\
\text { Desa }\end{array}$ & $\begin{array}{l}\text { Kepala } \\
\text { Desa }\end{array}$ \\
\hline
\end{tabular}

Selain itu sebagai guru PAUD, Yanti juga sering mendapati murid-murid PAUDnya yang berstatus CLB cenderung menjadi pendiam di dalam kelas.

Untung adalah kepala desa di sebuah desa di Banyumas, dan memiliki kepedulian terhadap BMI dan keluarganya. Pengalaman dia selama hampir 10 tahun menjadi sopir yang memberangkatkan BMI ke Jakarta, dapat merasakan bahwa BMI adalah korban pemerasan yang berlapis dari banyak pihak. Pengalaman masa lalunya menjadi bagian dari rantai pemerasan $\mathrm{BMI}$, membuatnya sekarang ingin menebus kesalahan dengan peduli kepada persoalan BMI di lingkungannya

\section{Pola asuh yang diterapkan ayah}

Berdasarkan penuturan para informan, ayah memegang peran yang signifikan selama ibu bekerja ke luar negeri. Ayah dituntut untuk dapat menggantikan semua peran ibu mulai dari menyiapkan makanan, mengantar sekolah, menemani saat tidur, dan juga membawa berobat saat sakit. Saat anak masih usia balita, ayah relatif bisa menjalankan fungsi-fungsi tersebut meskipun terkadang keluarga besar ikut membantu. Namun, pada kasus Bunga, Didik, Budi dan Kiki, menunjukkan masa-masa balita ayah adalah sosok yang selalu mendampingi semua kebutuhan primer anak. Budi bercerita bahwa semua kebutuhan fisiknya dan adiknya yang berusia 6 tahun, bisa dilakukan oleh ayahnya. Saat dia dan adiknya sakit, menyuapi, memandikan semua bisa dilakukan oleh ayahnya.

Bunga menceritakan ibunya bekerja di Hong Kong saat dia masih berusia 5 tahun, sehingga hari-harinya dilalui bersama sang ayah yang selalu mendampinginya dan kadang-kadang bermain dengan Budhe (kakak ibunya). Dia baru merasakan kesepian saat menginjak usia remaja dan mulai menstruasi. Pada awal-awal dia merasa kebingungan dan tidak tahu harus bercerita kepada siapa. Bunga seringkali mengalami rasa sunyi dan sedih saat mebutuhkan teman bercerita dan menceritakan yang dirasakan dan dialaminya karena ibunya tidak berada disampingnya. Meskipun dia bisa bercerita kepada ayahnya, namun ada masa-masa dia merasa sangat membutuhkan ibu hadir secara fisik dan ada disampingnya. Mulai tahun 2010, ketika teknologi informasi mulai banyak digunakan, ibunya membelikan dia laptop sehingga dapat berkomunikasi melalui skype. Selain itu ketika usianya mulai menginjak remaja, Bunga juga 
diberikan kepercayaan oleh ibunya untuk membuka rekening sendiri dan diawasi pemakaiannya melalui internet banking yang selalu dipantau oleh Keksi. Peran suami yang cukup demokratis dan amanah dalam menjaga anaknya kemudian diimbangi dengan peran Keksi yang selalu mengontrol dan mengelola keuangan keluarganya dengan baik termasuk mengontrol pendidikan anak-anaknya, mengantarkan anak satu-satunya, saat ini berhasil menyelesaikan sekolahnya di sebuah SMAN favorit di Purwokerto. Hal ini sesuai dengan pernyataan Keksi berikut ini:

"Saat masih di Hong Kong, saya
selalu mengontrol segala kiriman
untuk biaya pendidikan Bunga
dengan cara membuatkan
rekening khusus untuk dia. Dari
Hongkong saya memberikan
saran pada anak saya untuk ketat
mengelola uangnya mulai dari
biaya untuk les, biaya sekolah
dan lain-lain. Saya juga bisa
mengakses tabungan anak saya
dari Hong Kong melalui internet.
Hal ini membuat remiten ekonomi
hasil kerja keras saya selama di
Hong Kong menjadi relatif aman
dan dimanfaatkan sesuai
harapan. Alhamdulillah suami
saya termasuk orang yang
bertanggung jawab dan dapat
dipercaya. Beda sekali dengan
cerita-cerita teman saya tentang
suami mereka yang tidak bisa
mengurus anak dan
menghambur-hamburkan uang
kiriman istri yang bekerja. Suami
saya termasuk suami prihatin dan
tidak neko-neko"

Kondisi berbeda dialami oleh Didik, yang meskipun mengakui ayahnya berperan untuk mengurus kebutuhan fisik dia seperti menyediakan makan dan mengurusi saat dia sakit. Ayahnya cenderung keras, tidak komunikatif, cenderung mengabaikan dan tidak peduli dengan anak. Ayahnya yang berprofesi sebagai tukang batu hanya memperhatikan kebutuhan fisiknya saja dan tidak memahami kebutuhan-kebutuhan mental spiritualnya. Hal itu yang membuat Didik kehilangan figur ibu dan ayah secara bersamaan. Selepas SMP, Didik sempat sekolah di sebuah STM swasta di Purwokerto tapi kemudian dikeluarkan karena sering membolos. Sempat meneruskan pada pendidikan nonformal di sebuah sekolah menengah Purwokerto dan lagi-lagi dia dikeluarkan karena melakukan pelanggaran berat. Tepat setahun yang lalu, dua bulan sebelum ibunya kembali dari Arab, Didik ditangkap polisi karena melakukan pencurian bersama teman-temannya. Ibunya yang baru kembali dari Arab sekitar sepuluh bulan yang lalu, harus mendapati kenyataan yang menyakitkan, anak pertamanya masuk penjara. Harus diakui, komunikasi antara lbu, Didik, dan Ayahnya memang tidak harmonis, sehingga ikatan (bonding) diantara mereka menjadi tidak kuat dan Didik menjadi kehilangan panutan dalam keluarga.

Kondisi yang terjadi pada Didik, juga ditemukan oleh Yanti dan Untung, meskipun mereka tinggal di desa yang berjauhan. Yanti pernah mendapati pada keluarga besarnya, meskipun yang bekerja ke luar negeri adalah ayahnya, namun karena ayah tidak bisa menjadikan dirinya sebagai pemegang kontrol dan bertanggungjawab untuk mengawasi keluarga, justru ibu yang ada di rumah kewalahan menghadapi anak laki-lakinya yang sudah mulai remaja dan banyak menuntut dibelikan barang-barang misalnya motor, dan akan melawan atau merusak rumah jika keinginannya tidak dituruti.

Mbah Karto yang sudah lebih dari 10 tahun putus komunikasi dengan istrinya yang tidak diketahui lagi kabarnya, juga mengembangkan pola asuh yang mengayomi, bahkan saat anaknya sakit, dia sendiri yang akan menggendong sampai Puskesmas. Selain itu, dia selalu mengajarkan kepada anaknya untuk prihatin dan memahami kondisi orang tua yang memiliki keterbatasan-keterbatasan. Konsep prihatin bermakna sangat luas, tidak hanya membatasi diri pada hal-hal yang bersifat duniawi, tapi ada proses transedental untuk terus memohon pertolongan kepada Tuhan Yang Maha Kuasa dalam menjalani kehidupan ini agar lebih baik. Satu hal yang paling penting menurut penuturan para informan adalah kemauan para ayah untuk belajar memahami kebutuhan anak-anaknya. Menurut Sularso, ayah dua orang CLB; selama ditinggal istrinya, dia mengembangkan pola asuh yang dinamis, kadang keras tapi juga kadang lembut.

Menurut pengamatan Pak Untung, seorang Kepala Desa di Banyumas, masa-masa rawan anak CLB adalah saat remaja. Berdasarkan pengamatannya, anak-anak yang ditinggal ayahnya relatif lebih "aman" dibandingkan jika yang pergi ke luar negeri adalah ibunya karena ibu biasanya lebih bisa mengontrol dan mengendalikan keluarganya. Selain itu juga 
ada proses stigmatisasi bahwa jika yang pergi ke luar negeri adalah ibu maka menjadi "biasa" jika keluarganya tidak terurus dan berantakan. Dalam terminologi bahasa Banyumas, diistilahkan "memperlah ditinggal ibune kerja neng luar ya anake mbejut", semacam ada proses self fulfilling prophecy bagi anak-anak CLB untuk berbuat tidak baik karena tidak ada ibu diantara mereka. Oleh karenanya dianggap wajar kalau anak-anak yang ditinggalkan berbuat tidak sesuai norma yang berlaku dalam masyarakat. Untuk mengatasi kenakalan remaja CLB, bersama-sama dengan paguyuban BMI Seruni dan Pusat Penelitian Gender Anak dan Pelayanan Masyarakat LPPM Unsoed, pak Untung pada tahun 2015 mengadakan pelatihan untuk kelompok pendamping bagi anak-anak remaja CLB sehingga anak remaja memiliki tempat untuk berbagi saat menghadapi kesulitan.

\section{PEMBAHASAN}

Pola asuh yang diterapkan orang tua akan memberikan pengaruh pada perilaku anakanaknya. Berdasarkan deskripsi tentang peran ayah yang telah disampaikan dan penjelasan para informan menunjukkan bahwa ayah berperan dalam setiap kegiatan menyediakan dan menyiapkan kebutuhan fisik anak saat istrinya tidak ada di rumah. Menurut Cabrera et al. (2000) dan Kwok et al. (2013), pengasuhan ayah akan memengaruhi perkembangan dan kesejahteraan anak, termasuk ketika anak memasuki masa transisi menuju remaja. Ayah yang mengasuh dan melindungi anaknya dengan baik akan memberikan dampak yang positif terhadap tumbuh kembang anak sehingga berdampak terhadap kesejahteraan psikologis ayah juga.

Namun pemenuhan kebutuhan fisik saja tidak cukup karena juga harus diiringi dengan pola asuh dan pola komunikasi yang baik. Faktafakta yang telah tersaji menunjukkan bahwa kebutuhan dasar sebagai seorang anak, khususnya yang terkait dengan kebutuhan psikologis khususnya lagi ketika ada di masa remaja, tidak sepenuhnya terpenuhi. Padahal untuk dapat tumbuh dan berkembang secara optimal, pemenuhan kebutuhan anak tidak hanya cukup dari pemenuhan kebutuhan fisik saja. Hasil penelitian Harmaini, Sofiah, dan Yulianti (2014), peran ayah dalam pengasuhan dari pandangan anak adalah sebagai kepala keluarga dan sebagai figur perlindungan untuk anak, yang mana dukungan finansial adalah bagian penting yang tidak dapat terpisahkan dari seorang ayah. Titi dalam Soetjiningsih (1995) menyebutkan bahwa ada tiga golongan kebutuhan dasar anak, yaitu: (1) Asuh yang merujuk pada kebutuhan fisik dan biomedis, seperti kebutuhan pangan (gizi), perawatan kesehatan dasar pengobatan (jika sakit), tempat tinggal yang layak, lingkungan yang bersih, pakaian, rekreasi, dan lain sebagainya; (2) Asih yang merujuk pada kebutuhan emosi dan kasih saying, yang mencakup hubungan yang erat, mesra dan selaras antara ibu atau pengganti ibu dengan anak yang juga menjadi syarat mutlak untuk menjamin tumbuh kembang yang optimal bagi fisik, mental maupun psikososial, dan berperan dominan pada tahun-tahun pertama kehidupan anak; dan (3) Asah yang merujuk pada kebutuhan stimulasi (rangsangan atau dorongan) mental, yang mencakup rangsangan yang menjadi dasar dalam proses belajar anak dan bertujuan mengembangkan mental dan psikososial yaitu kecerdasan, keterampilan, kemandirian, kreativitas, agama, kepribadian, moral etika, dan lain sebagainya serta bisa dilakukan dengan memberi apresiasi (pujian) ketika anak mampu melakukan suatu hal, mengajak anak melakukan beberapa pekerjaan ringan dalam keluarga, dan lain sebagainya.

Idealnya, ayah sebagai pengasuh utama di rumah selama ibu tidak ada bisa mengembangkan pola asuh, asih, dan asah tersebut. Harmaini, Sofiah, dan Yulianti (2014) menyatakan bahwa dari pandangan anak, pengasuhan ayah lebih ke arah pemenuhan kebutuhan afeksi, mengasuh, dukungan dan finansial. Chaudhary Tuli, dan Sharda (2015) menyatakan bahwa indikator pengasuhan ayah diantaranya aktif dalam membesarkan anak, menyayangi, memberi makan, membersihkan dan memberikan perlindungan kepada anak. Persoalan tentang pola asuh ayah, juga terkait pembagian peran gender antara suami (ayah) dan istri (ibu).

Suami atau ayah mengambil peran instrumental (instrumental role) yang berkaitan dengan membantu memelihara sendi-sendi masyarakat dan keutuhan fisik keluarga dengan jalan menyediakan bahan makanan, tempat perlindungan, dan menjadi penghubung keluarga dengan dunia luar. Pria dihadapkan dengan kebutuhan untuk mengambil tugas perawatan anak, yang secara tradisional dianggap tugas wanita, sementara pada saat yang sama berada di bawah tekanan besar untuk memenuhi citacita maskulinitas yang diterima secara umum (Hoang \& Yeoh, 2011). Sementara itu, istri atau ibu mengambil peran ekspresif (expresif role) membantu mengeratkan hubungan, 
memberikan dukungan emosional dan menjamin kelancaran urusan rumah tangga. Pembagian peran gender itu, mau tidak mau telah membentuk pembagian kerja antara ayah dan ibu. Hal ini pada akhirnya berimplikasi pada relasi orang tua dan anak. Hal ini berarti meskipun sama-sama menimbulkan dampak bagi anak, namun kepergian ibu dalam jangka waktu yang lama untuk bekerja ke luar negeri, memberikan dampak yang lebih berat baik secara psikologis maupun secara sosiologis.

Hal tersebut dapat terjadi karena antara anak dan ibu sudah terjalin ikatan (bonding) yang dimulai sejak anak dalam kandungan. Perpisahan antara ibu dan anak dalam jangka waktu yang relatif lama dapat merenggangkan bonding antara anak dan ibu sehingga menyebabkan tidak terbangunnya basic trust dan menimbulkan kesulitan-kesulitan tingkah laku dalam perkembangan kepribadian anak selanjutnya. Gunarsa (2003) menyebutkan bahwa basic trust dan kepribadian anak merupakan landasan dalam perkembangan sosial anak untuk dapat menjalin hubungan dengan orang lain. Perpisahan dengan ibu untuk jangka waktu yang lama (minimal 2 tahun) jika kemudian tidak dibarengi dengan "kerja keras" ayah dalam berperan menggantikan semua peran ibu (ekspresif role) tentunya akan berakibat anak akan kehilangan kasih sayang dan basic trust di atas. Hasil penelitian Graham dan Jordan (2011) beberapa dari anak-anak mungkin menderita tekanan psikologis akibat perpisahan dari orang tua. Di Asia Tenggara, perhatian terutama terfokus pada anak-anak ibu migran, yang dianggap paling berisiko terkena dampak negatif. Menurut Huang dan Yeoh (2005), keluarga merupakan penentu rencana dan keputusan untuk memilih anggota keluarga melakukan migrasi.

Hasil penelitian Yahya (2017) memperlihatkan bahwa ayah yang ditinggalkan ibu menjadi Buruh Migran Perempuan (BMP) ke luar negeri tidak dapat hanya mengandalkan bantuan dari keluarga luas dalam mengasuh anak, tetapi ayah jugaharus bisa terlibat langsung dalam mengasuh anak. Intensitas keterlibatan ayah dalam pengasuhan akan berhubungan dengan usia dan terpengaruh juga dari jumlah anak yang harus ayah asuh. Ayah dengan usia yang lebih muda akan lebih bisa terlibat dalam mengasuh anak karena akan tersisa sedikit tenaga untuk berbicara atau bermain dengan anak sepulang dari mencari nafkah. Jumlah anak yang dimiliki ayah akan sangat memengaruhi ayah dalam mengasuh anak, ayah yang hanya memiliki seorang anak akan lebih mudah mengurus anak karena jumlah anak yang harus diasuh hanya seorang saja. Berbanding terbalik dengan ayah yang memilikilima orang anak, ayah akan kesulitan apa bila harus mengasuh lima orang sekaligus dan ayah juga harus mencari nafkah. Saat anak-anak mulai menginjak usia remaja dan permasalahan pergaulan semakin kompleks, nampak kebutuhan para informan akan sosok ayah yang lebih komunikatif, bisa mencurahkan perhatian, bisa mendengarkan keluhankeluhan dan kegelisahan serta bisa dijadikan panutan dan memegang kendali atas anakanak mereka yang sudah mulai menginjak remaja. Orang tua memegang peran utama dalam konsep pembentukan diri anak, sehingga ketika ibu dan ayah tidak bisa menjalankan perannya maka konsep diri anak akan mengalami persoalan. Hal ini karena selama ini ayah memang tidak dikonstruksikan untuk menjadi pengasuh anak. Marcus dan Betzer (1996) memperlihatkan bahwa kelekatan ayah dengan anak merupakan faktor prediktor penting yang menentukan perilaku antisosial anak dan terdapat hubungan negatif antara kelekatan dan perilaku antisosial.

Pola asuh yang dikembangkan oleh orang tua informan menunjukkan fakta yang berbedabeda. Ada yang cenderung membiarkan dan tidak peduli, ada yang turut serta dan mengawasi anak. Menurut Elizabeth (2012), ada empat tipe pola asuh yaitu otoriter, otoritatif, permissive indifferent, permissiveindulgent. Pola asuh otoriter adalah pula asuh yang membatasi dan menghukum serta menuntut anak untuk menuruti perintah orang tua dan tidak memberikan peluang yang besar kepada anak untuk berbicara. Pola asuh otoritatif, anak didorong untuk mandiri, tetapi masih menetapkan batas dan pengendalian atas perilaku anak, orang tua menunjukkan kehangatan dan kasih sayang kepada anak. Pola yang ketiga adalah permissive indifferent, yaitu pola asuh yang mana orang tua sangat tidak terlibat dalam kehidupan anak. Anak merasa keberadaan tidak begitu penting bagi orang tua. Tipe pola asuh keempat adalah permissive-indulgent, yakni pola asuh yang mana ayah dan ibu sangat terlibat dalam kehidupan anak, tetapi menetapkan sedikit batasan/kendali terhadap anak. Konsep ini tidak jauh berbeda dengan konsep pola asuh menurut Baumrind (Santrock, 2002) yang membagi empat macam bentuk pola asuh adalah sebagai berikut: Pola asuh otoriter; pola asuh otoritatif atau demokrasi, Pola asuh penelantaran dan pola asuh orang tua 
permisif. Pola asuh penelantaran menurut Baumrind bisa disejajarkan dengan permisif indifferent. Berdasarkan kategori pola asuh di atas, ayah Didik cenderung bersikap permissive indifferent atau penelantaran dan hal ini diperparah dengan tidak berjalan harmonisnya komunikasi antara Didik dan ibunya, juga ibu dengan ayahnya.

CLB yang sudah berusia remaja terlihat harus dikembangkan pola asuh yang bersifat otoritatif atau demokratis yang berarti anak didorong untuk mandiri, tetapi masih menetapkan batas dan pengendalian atas perilaku anak, disini orang tua menunjukkan kehangatan dan kasih sayang kepada anak. Dukungan dan keterlibatan ayah baik dalam hal pengasuhan dan teladan yang diberikan oleh sangat memengaruhi dalam proses perkembangan remaja dan dalam pengendalian diri remaja terhadap perilaku berisiko (Husna \& Hastuti, 2015). Berdasarkan penuturan para CLB, anak sangat berharap bahwa ayah dan ibunya bisa menerapkan pola asuh yang demikian. Selain itu diharapkan dilakukan oleh ayah yang sehari-hari mendampingi anak, ibu yang sedang bekerja ke luar negeri juga diharapkan bisa memperbaiki kualitas komunikasi lebih baik dan memperhatikan sampai hal-hal yang detail seperti yang dilakukan oleh Keksi. Hal itu akan menumbuhkan rasa nyaman dan tenang pada anak. Hal ini juga disampaikan oleh Budi dan Bunga. Kedekatan dan pola asuh yang dikembangkan ayah mereka membuat merasa dipercaya dan tumbuh bahagia. Temuan ini hampir sama dengan hasil penelitian Flouri (2005) yang menemukan bahwa keterlibatan ayah dalam kehidupan anak berkorelasi positif dengan kepuasan hidup dan kebahagiaan anak. Hal ini juga didukung hasil penelitian Fitriani dan Hastuti (2016) yang menunjukkan bahwa kelekatan dengan ayah memiliki pengaruh negatif signifikan terhadap kenakalan remaja. Temuan Hidayati et al. (2011) juga menjelaskan bahwa menguatnya kesadaran pentingnya peran ayah yang multifungsi dalam proses pengasuhan bersama ibu akan meningkatkan kualitas pendidikan keluarga $\mathrm{Hal}$ ini menunjukkan bahwa kelekatan tidak aman dengan ayah memberikan pengaruh pada tingkat kenakalan remaja. Temuan Susanto (2013) juga menunjukkan bahwa semakin tinggi (positif) keterlibatan ayah dalam pengasuhan, maka semakin tinggi resiliensi remaja, dan sebaliknya semakin rendah keterlibatan ayah dalam pengasuhan, maka semakin rendah resiliensi remaja. Berdasarkan beberapa hasil penelitian tersebut keterlibatan ayah para CLB dengan pola asuh yang demokratis (autoritatif) akan menjadikan anak-anak merasa nyaman sehingga ketahanan keluarga selama ditinggal ibu bekerja ke luar negeri menjadi utuh dan kuat. Berdasarkan penuturan para informan pendukung, nampak ada kebutuhan belajar ilmu tentang pengasuhan ayah (fathering), yang mana ayah diajarkan teknik mengasuh anak yang baik sesuai usianya, memperhatikan unsur tumbuh kembang anak dan mendengarkan kebutuhan-kebutuhan anak. Tidak hanya sekedar kebutuhan fisik namun juga kebutuhan mental, sosial dan religiusnya. Peran ayah di dalam pengasuhan anak memberikan gambaran yang cukup positif di berbagai aspek, baik waktu, perhatian dan interaksi (Hidayati, Kaloeti, \& Karyono, 2011).

\section{SIMPULAN DAN SARAN}

Selama ditinggalkan istrinya bekerja ke luar negeri, ayah berperan penting dalam mengasuh anak-anaknya. Saat anak masih balita, ayah bisa menjalankan peran instrumental dan ekspresif dengan baik. Semua kebutuhan CLB mulai dari menyiapkan makanan, mengantar sekolah, menemani saat tidur juga membawa berobat saat sakit bisa dilakukan oleh ayah. Saat para CLB mulai menginjak usia remaja dan permasalahan pergaulan semakin kompleks, sosok ayah yang dibutuhkan harus lebih komunikatif, bisa mencurahkan perhatian, bisa mendengarkan keluhan-keluhan dan kegelisahan serta bisa dijadikan panutan dan memegang kendali atas anak-anak yang sudah mulai menginjak remaja. Keluarga CLB yang utuh akan tercipta jika ayah tangguh, yang artinya jika para ayah yang ditinggal oleh istrinya bekerja ke luar negeri memiliki kekuatan dan ketangguhan, mau bekerja keras, serta prihatin dan mau belajar tentang pola asuh yang lebih otoritatif, maka keluarga akan bisa terjaga keutuhannya. Ayah juga perlu diajarkan ilmu tentang fathering (pengasuhan ayah) sehingga mampu mengasuh anak sesuai usia dan tumbuh kembangnya.

Mekanisme yang efektif untuk melindungi anak-anak CLB adalah kedepan perlu penguatan peran komunitas untuk mengasuh CLB. Komunitas memiliki potensi untuk membangun sistem pengasuhan bagi anak BMI secara efektif karena berasal dari inisiatif masyarakat (bottom up) dan secara konstektual disesuaikan dengan kondisi dan permasalahan CLB yang ada di komunitas masing-masing. Pemerintah perlu membangun mekanisme untuk melindungi CLB, baik 
melalui penguatan kebijakan maupun penguatan kelembagaan pada masyarakat pengirim Buruh Migran Indonesia (BMI).

\section{DAFTAR PUSTAKA}

[BKKBN NTB] Badan Koordinasi Keluarga Berencana Nasional Nusa Tenggara Barat. 2009. Ratusan Ribu Anak Terlantar di NTB. [diunduh pada 29 Feb 2009]. Tersedia pada http: //prov.bkkbn.go.id/ntb/news_detail.php?n $\mathrm{id}=316$.

[BNP2TKI] Badan Nasional Penempatan dan Perlindungan Tenaga Kerja Indonesia. (2016). Data penempatan dan perlindungan tenaga kerja Indonesia tahun 2015. Pusat Penelitian dan Pengembangan Informasi BNP2TKI. Diambil dari http://www.bnp2tki.go.id/uploads/data/da ta_01-02-

2016 122032 Laporan_Pengolahan_Da ta_BN̄P2TKI_TAHUN_2015.pdf.html. [diunduh pada 15 Mei 2016)

[UNICEF] United Nations Children's Fund. (2010) The Children Left Behind ( $A$ League table of inequality in child well being in the world rich countries), Folrence, Innocenti Report Card 9

Blood, Jr., Robert, O. (1972). The Family. New York: The Free Press.

Botezat, A., \& Friedhelm, P. (2014). The impact of parents migration on the well being of children left behind initial evidence from Romania, Germany, IZA. Discussion Paper: Forschungsinstitutzur Zukunft der Arbeitlnstitute for the Studyof Labor

Brooks, J. (2001). Parenting, Third Edition. California: Mayfield Publishing Company

Cabrera, N., Tamis-LeMonda, C., Bradley, R., Hofferth, S., \& Lamb, M. (2000). Fatherhood in the twenty-first century. Child Development. 71(1), 127-36.

Chaudhary, N., Tuli, M., \& Sharda, S. (2015). Father-Paternity: Fathers. Encyclopedia on Early Childhood Development

Cortes, R. (2008). Children and women left behind in labour Sending Countries: an appraisal of social risks. New York: UNICEF

Dissayanake, P.L., Chandrasekara, N.V., \& Jayasundara, D.D.M. (2014). The impact of mothers migration for work abroad on children's education in Sri Lanka.
European International Journal of Science and Technology, 3(1), 110-120

Fitriani, W., \& Hastuti, D. (2016). Pengaruh kelekatan remaja dengan ibu, ayah, dan teman sebaya terhadap kenakalan remaja di Lembaga Pembinaan Khusus Anak (LPKA) Kelas II Bandung. Jurnal IImu Keluarga Dan Konsumen, 9(3), 206-217,

DOI: http://dx.doi.org/10.24156/jikk.2016.9.3.2 06

Flouri, E. (2005). Fathering and child outcomes. West Sussex, England: John Wiley \& Sons Ltd

Gao, Y., Li, L.P., Kim, J.H., Congdon, N., Lau, J., \& Griffiths, S. (2010). The Impact of Parental Migration on Health Status and Health Behaviours among Left Behind Adolescent School Children in China. BMC Public Health, 10(56), DOI: https://doi.org/10.1186/1471-2458-10-56

Goode, W. J. (2007). Sosiologi Keluarga. Jakarta: PT Bumi Aksara.

Graham, E., \& Jordan, L. P. (2011). Migrant parents and the psychological well-being of left-behind children in Southeast Asia. Journal of Marriage and Family 73 (4): 763 - 787. DOI:10.1111/j.1741 3737.2011.00844.x.

Gunarsa. (2003). Dasar dan teori perkembangan anak. Jakarta, ID: Gunung Mulia.

Harmaini, Sofiah, V., Yulianti, A. (2014). Peran ayah dalam mendidik anak. Jurnal Psikologi. 10(2), 80-85

Hidayati, F., Kaloeti,D. V. S.Karyono. (2011). Peran ayah dalam pengasuhan anak, Jurnal Psikologi Undip Semarang, 9 (1 ):1-10, DOI: https://doi.org/10.14710/jpu.9.1.

Hoang, L.A., \& Yeoh, B.S.A. (2011). Breadwinning wives and "left-behind" husbands men and masculinities in the Vietnamese transnational family. Gender \& Society, 25 (6),717 - 739. DOI: $10.1177 / 0891243211430636$

Huang, S., \& Yeoh, B. S. (2005). Transnational families and their children's education: China's 'study mothers' in Singapore. Global Networks 5, 4: 379-400, DOI: https://doi.org/10.1111/j.14710374.2005.00125.x

Husna, F., \& Hastuti, D. ( 2015). Ayah permisif meningkatkan risiko anak untuk merokok. Jurnal IImu Keluarga dan 
Konsumen, 8(3), 153-162, DOI: http://dx.doi.org/10.24156/jikk.2015.8.3.1 53

Kustini. (2002). Perceraian di kalangan buruh migran perempuan : studi kasus di Desa Kadupura Kabupaten Sukabumi Provinsi Jawa Barat, (Tesis). Institut Pertanian Bogor, Bogor, Indonesia.

Kwok, S., Ling, C., Leung, C., Li, J. (2013). Fathering self-efficacy, marital satisfaction and father involvement in Hong Kong. Journal Children Families Study. 22(8), 1051-1060

Lam, T., Yeoh, B.S.A., \& Hoang, L.A. (2013). Transnational Migration and Changing Care Arrangements for Left-Behind Children in Southeast Asia: A Selective Literature Review in Relation to the CHAMPSEA Study. Asia Research Institute Working Paper Series. 207.

Mantra, I. B., Kasto., Yeremias, K. (1998) Migrasi Tenaga Kerja Malaysia: Determinan, Dampak dan Kebijakan Laporan Penelitian Hibah Bersaing VI/I Perguruan Tinggi Tahun Anggaran 1997/1998. Yogyakarta PPK UGM

Marcus, R. F. \& Betzer, P. D. (1996). Attachment and antisocial behavior in early adolescence. Journal of Early Adolescence, 16 (2), 229-248

Narsidah, Wulan, T.E., Wahyuningsih, E., Setyawati, \& Mahmuda. (2016). Pengasuhan Anak BMI Berbasis Komunitas. Yogyakarta: Seruni, Tifa, dan Global Workers Organization Taiwan.

Nobles, J. (2013). Migration and father absence:shifting family structure in Mexico. Demography. 50(4),1303-1314, DOI: $10.1007 / \mathrm{s} 13524-012-0187-8$.

Pranowo, D.E., Wulan, T.R., Widyastututi, T.R. (2013). Mendengar Suara Anak Keluarga Buruh Migran Perempuan (BMP) (Studi tentang Kehidupan Anak Keluarga BMP di Desa Banjarparakan Kecamatan Rawalo Kabupaten Banyumas) (Skripsi), Universitas Jendral Soedirman, Purwokerto, Indonesia

Puspitawati, H. (2013). Pengantar Studi Keluarga. Bogor [ID] : PT Penerbit IPB Press.

Puspitawati, H., \& Setioningsih, S. S. (2011). Fungsi pengasuhan dan interaksi dalam keluarga terhadap kualitas perkawinan dan kondisi anak pada keluarga Tenaga Kerja Wanita (TKW). Jurnal IImu Keluarga dan Konsumen, 4(1): 11-20, DOI: http://dx.doi.org/10.24156/jikk.2011.4.1.1 1

Restuadhi, H. (2016) Suami Buruh Migran antara Hasrat Seksual dan HIV/AIDS, diterbitkan atas kerjasama Jurusan Sosiologi FISIP Unsoed dan Pusat Penelitian Gender, Anak dan Pelayanan Masyarakat LPPM Unsoed, Yogyakarta: Tab Grafika

Seruni. (2014). Pembangunan Strategi Pola Pengasuhan Children Left Behind (CLB) berbasis Komunitas Kabupaten Banyumas. Tidak dipublikasikan.

Soetjiningsih. (1995). Tumbuh Kembang Anak. Jakarta: EGC.

Sukamdi. (2015). Dampak migrasi internasional terhadap keluarga dan anak yang ditinggalkan: studi kasus Indonesia. Presented in Seminar on Indonesian Migrant Workers of SMERU, BAPPENAS, and UNICEF, Jakarta, 15 December 2015.

Sukamdi. (2001) Female Labour Migration in South East Asia: Change and Continuity. Indonesia, Philippines, Thailand and Yunnan (China): PPK UGM and Asia Pacific Migration Research Network

Susanto, M.D. (2013). Keterlibatan ayah dalam pengasuhan, kemampuan coping, dan resiliensi remaja. Jurnal Sains dan Praktik Psikologi. 1 (2) : 101113.

Tamtiari, W. (1999). Dampak sosial migrasi tenaga kerja ke Malaysia Populasi, 10(2), 39-56

Tamtiari, W. (2000). Dampak migrasi tenaga kerja ke malaysia (studi kasus implementasi kebijakan migrasi di Lombok Timur, NTB) (Tesis). Universitas Gajah Mada, Yogyakarta, Indonesia

Wahyuningsih, E., \& Wulan, T.R. (2016). The Profile of Caregiver and Problems of Children Left Behind (CLB) Among Indonesian Migrant Worker Families. Dipresentasikan pada International Workshop on Maximising Migration Benefits (M2B): Indonesian Migrant Workers' Health and Wellbeing from Security to Development Jakarta, 1921 September 2016. 
Wulan, T. R, Dalhar, S., Soetji, L, \& Rili, W. (2010). Buruh migran perempuan:melawan negara dan pasar dengan remitansi sosial. Jurnal Analisis Sosial Akatiga Bandung, 15

Wulan, T. R. (2010). Pengetahuan dan kekuasaan: pegetahuan dan kekuasaan: penguatan remitansi sosial sebagai strategi pemberdayaan buruh migran perempuan Indonesia, (Disertasi), Institut Pertanian Bogor, Bogor, Indonesia
Wulan, T. R., Dalhar, S., Sri, W., \& Margani, P. (2013). From zero to hero: strengthening social and economic remittance as strategy to the empowerment of female migrant workers. Seminar Internasional SEADI dan TNP2K

Yahya, F. (2017). Faktor-faktor yang memengaruhi kesejahteraan subjektif ayah dan anak pada keluarga Tenaga Kerja Wanita (TKW), (Tesis), Institut Pertanian Bogor, Bogor, Indonesia 